\title{
Pendampingan Pembuatan Laporan Keuangan Dan Laporan Perpajakan Bagi UMKM Di Kota Cirebon
}

\author{
Moh. Yudi Mahadianto ${ }^{1}$, Ramlah Puji Astuti ${ }^{*}$, Firman Hidayat ${ }^{3}$ \\ Universitas Swadaya Gunung Jati Cirebon \\ 1e-mail: mohyudim@yahoo.co.id \\ 2e-mail:ramlah_astuti@yahoo.co.id \\ 3e-mail: firmanhidayat489@gmail.com \\ *Corresponding Author
}

\begin{abstract}
ABSTRAK
Perkembangan UMKM di Kota Cirebon tak luput dari berbagai permasalahan yang ada. Permasalahan yang dihadapi oleh UMKM adalah masih rendahnya kesadaran pelaku UMKM dalam membuat laporan keuangan. Selain itu rendahnya kesadaran dan pemahaman pelaku UMKM terhadap perpajakan juga menjadi masalah dalam perkembangan UMKM. Sehingga perkembangan UMKM tidak sejalan dengan kontribusinya terhadap peningkatan pajak di Kota Cirebon. Kegiatan pendampingan kali ini akan memfokuskan pada pentingnya membuat laporan keuangan untuk UMKM serta peningkatan kepatuhan pelaporan perpajakan UMKM. Metode yang digunakan dalam pendampingan kali ini adalah metode pendampingan secara langsung yang melibatkan peran pelaku UMKM dalam fokus kajian. Tahap awal dilakukan sosialisasi kepada pelaku UMKM. Selanjutnya diberikan pelatihan mengenai pelaporan Keuangan dan pelaporan perpajakan. Terakhir pelaku UMKM diberikan pendampingan dalam membuat laporan keuangan dan pelaporan perpajakan. Hasil kegiatan pendampingan ini terlihat dengan adanya peran serta aktif dari pelaku UMK untuk mulai membuat catatan aktivitas keuangan usahanya selama beberapa minggu terakhir saat masa evaluasi dan monitoring. Kegiatan ini memberikan dampak yang positif sehingga dapat di rekomendasikan untuk kegiatan pendampingan selanjutnya dengan fokus yang lainnya. Penerapan Peraturan pemerintah mengenai tarif pajak UMKM menjadi 0,5\% belum banyak diketahui masyarakat. perlu peran serta masing-masing pemangku kepentingan untuk meningkatkan kegiatan ekonomi UMKM yang akan berakibat pada peningkatan perekonomian negara.
\end{abstract}

Kata kunci : UMKM; Laporan Keuangan; Laporan Perpajakan

\begin{abstract}
The development of MSMEs in Cirebon cannot be spared from various existing problems. The MSMEs problem is the low awareness of making financial reports. The role of MSMEs in the economy and employment is not in doubt. Unfortunately there is a miss match between the high potential of MSMEs and their tax compliance. MSMEs tax reporting still does not reflect the maximum contribution as it affects the economy and employment. This mentoring activity will focus on the importance of making financial reports for MSMEs as well as increasing MSMEs tax reporting compliance. Furthermore, training was given on financial reporting and tax reporting. Finally, MSME actors are given assistance in making financial reports and tax reporting. The results of this mentoring activity can be seen from the active participation of MSMEs tentant to start making records of their business financial activities during the last few weeks during the evaluation and monitoring period. This activity has a positive impact so that it can be recommended for further mentoring activities with other focuses. The participation of each stakeholder is necessary to increase the economic activities of MSMEs which will result in an increase in the country's economy.
\end{abstract}

Keywords: MSMEs; Financial Reports; Tax Reports 


\section{PENDAHULUAN}

Sektor Usaha Kecil dan Menengah merupakan suatu usaha yang ikut berkontribusi besar dalam perekonomian Indonesia. Peran UMKM terhadap perekonomian dan penyerapan tenaga kerja tidak diragukan lagi (Inasius, 2015). Namun, pada sektor perpajakan UMKM masih belum mencerminkan kontribusi yang maksimal sebagaimana pengaruhnya terhadap perekonomian dan penyerapan tenaga kerja. Perkembangan UMKM di Indonesia merupakan salah satu indikator peningkatan perekonomian masyarakat yang terindikasi oleh peningkatan pendapatan masyarakat melalui sektor UMKM.

UMKM di Indonesia memiliki potensi yang sangat besar dan terbukti mampu bertahan dalam badai krisis moneter tahun 1997. Pada krisis global tahun 2008, UMKM juga justru menjadi penyelamat ekonomi nasional dari keterpurukan (Muizu, 2017). Potensi UMKM dilihat dari tingkat pertumbuhannya juga menunjukkan grafik yang terus meningkat. Salah satu daerah yang memiliki UMKM yang potensial adalah Kota Cirebon. Sebagai kota perdagangan, Kota Cirebon memiliki berbagai jenis UMKM unggulan seperti UMKM Batik, makanan olahan, rotan, perikanan dan lain-lain. Perkembangan UMKM di Kota Cirebon pun dari tahun ke tahunnya menunjukkan peningkatan yang signifikan. UMKM Kota Cirebon telah memberikan kontribusi bagi perkembangan Kota Cirebon. (Astuti, Kartono, \& Rahmadi, 2020).

Kota Cirebon merupakan wilayah yang sangat strategis di Provinsi Jawa Barat yaitu kota yang berbatasan langsung dengan provinsi lain, sehingga perkembangan ekonomi khususnya di perdagangan sangat signifikan. Selain itu, peningkatan perekonomian dapat dilakukan dengan meningkatkan kuantitas dan kualitas UMKM yang ada sehingga berdampak pada kesejahteraan penduduk Kota Cirebon. Jumlah Industri kecil di Kota Cirebon pada tahun 2018 sebanyak 1.920 unit. Berdasarkan jenis industrinya terlihat bahwa sebagian besar merupakan industri komoditi lainnya yaitu sebanyak 572 unit, kemudian industri kayu sebanyak 484 unit dan yang ketiga adalah industri makanan sebanyak 351 unit. Sementara pada industri rumah tangga pada tahun 2017 berjumlah 8.678 unit. Industri rumah tangga ini didominasi oleh industri makanan yang mencapai 2.858 unit, kemudian industri kayu sebanyak 1.566 unit dan industri lainnya sebanyak 1.441 unit. (Dinas Perdagangan, Koperasi 2019).

Pertumbuhan jumlah UMKM dari tahun 2005 sampai tahun 2018 meningkat sekitar 20,2\%. Sayangnya terdapat miss and match antara potensi yang tinggi dari UMKM dengan kepatuhan pajaknya. (Hardiningsih \& Oktaviani, 2013) Penerimaan pajak total yang memiliki porsi 80\% lebih terhadap APBN, kontribusi UMKM hanya sebesar kurang lebih 0,5\% (BPS, 2019). Rendahnya kepatuhan pajak UMKM ini disebabkan karena kebijakan pajak yang terlalu 
memberatkan mereka. Kesadaran wajib pajak sangat sulit diwujudkan, sampai sekarang kesadaran masyarakat masih belum mencapai tingkat sebagaimana yang diharapkan (Ibrahim, 2014).

Keputusan pemerintah menurunkan tarif pajak final UMKM dinilai tak banyak membantu dan memberikan insentif bagi UMKM. Sebelumnya pemerintah mengeluarkan peraturan yang cukup mengejutkan pada 1 Juli 2013 dengan menerapkan pajak 1\% bagi UMKM (PP, 2013). Peraturan tersebut dituangkan dalam PP 46 tahun 2013 yang dinilai sebagai bentuk penindasan pemerintah dengan kedok legislasi penyederhanaan perhitungan PPh terhadap pengusaha kecil. Penyederhanaan perhitungan PPh hanya merupakan kata pemanis yang sebetulnya menjadikan pengusaha kecil yang selama ini termarjinalkan menjadi korban (Fauziah \& Tidajoh, 2018).

Permasalahan lainnya yang dihadapi oleh UMKM yang ada di Indonesia adalah masih rendahnya kesadaran pelaku UMKM dalam membuat laporan keuangan. Masih rendahnya kesadaran pelaku UMKM terhadap pentingnya pencatatan keuangan usahanya. Banyak diantara pelaku UMKM yang masih belum memisahkan pendanaan usaha dengan pendapatan keluarga. Sehingga mereka belum mengetahui berapa omzet bersih yang mereka peroleh dari hasil usahanya. Oleh sebab itu banyak diantara mereka yang tidak mematuhi kewajiban melaporkan pajaknya kepada negara. Minimnya pengetahuan membuat sebagian besar pelaku UMKM enggan membuat dan mencatat laporan keuangan usahanya (Prabantari \& Ardiyanto, 2017).

Permasalahan tersebut dapat di atasi dengan berbagai langkah untuk meningkatkan kesadaran dan kepatuhan Pajak serta kapasitas bisnis UMKM di Kota Cirebon. Salah satu upaya yang dapat dilaksanakan adalah dengan melaksanakan "Pendampingan Pembuatan Laporan Keuangan dan Laporan Perpajakan bagi UMKM di Kota Cirebon” melalui pendampingan ini dapat meningkatkan kepatuhan dan kesadaran pajak pelaku UMKM dan meningkatkan pembuatan laporan keuangan bagi UMKM di Kota Cirebon. Tujuan program pengabdian masyarakat ini adalah untuk menumbuhkan kesadaran serta peran serta masyarakat terhadap pendapatan negara melalui sektor pajak. Khususnya Peningkatan kesadaran dan kepatuhan wajib pajak UMKM terhadap kewajiban perpajakannya. Sehingga dapat mengurangi bahaya investasi ilegal serta dapat meningkatkan transaksi di pasar modal yang berakibat meningkatkan pertumbuhan ekonomi masyarakat dan negara.

\section{BAHAN DAN METODE}

Metode yang digunakan dalam kegiatan pemberdayaan ini adalah metode partisipatif yaitu strategi pemberdayaan masyarakat yang mengutamakan partisipasi dari masyarakat, yang dilakukan dari mengidentifikasi masalah, menyusun program dan merencanakan solusi secara 
bersama-sama. Pelaksanaan pemberdayaan memposisikan masyarakat sebagai subyek yang aktif di dalam pelaksanaan kegiatan.

Pelaksanaan kegiatan Pemberdayaan ini dilakukan melalui dua tahap. Tahap yang pertama adalah pelatihan penulisan laporan keuangan kepada mitra UMKM melaui sosialisasi dan pendampingan tata kelola keuangan UMKM. Tahap yang kedua adalah melakukan sosialisasi dan pendampingan pelaporan pajak bagi UMKM. Khalayak sasaran pada program pengabdian masyarakat ini adalah pelaku UMKM di Kota Cirebon yang tergabung dalam UMKM Binaan KPP Pratama Cirebon 1.

Program pemberdayaan ini juga menggunakan metode monitoring dan evaluasi. Tahap ini dilakukan untuk melihat seberapa jauh program pemberdayaan ini terlaksana dengan baik sesuai dengan target pencapaian kegiatan seperti yang di rencanakan. Kegiatan monitoring dan evaluasi dilakukan dengan indikator pencapaian tujuan dan tolak ukur sebagai berikut:

Tabel 1. Indikator Pencapaian Kegiatan

\begin{tabular}{cllllc}
\hline No & \multicolumn{3}{c}{ Uraian Kegiatan } & Target & Tolak ukur \\
\hline 1 & $\begin{array}{l}\text { Meningkatkan kesadaran pelaku UMKM terhadap } \\
\text { pelaporan pajak }\end{array}$ & 52 tenant & $\begin{array}{c}\text { Kesadaran } \\
\text { pentingnya pajak } \\
\text { bagi negara }\end{array}$ \\
\hline 2 & $\begin{array}{l}\text { Meningkatkan kepatuhan } \\
\text { membayar pajak }\end{array}$ & pelaku UMKM & untuk & 52 tenant & $\begin{array}{c}\text { Kepatuhan } \\
\text { membayar pajak }\end{array}$ \\
\hline 3 & $\begin{array}{l}\text { Meningkatkan partisipasi pelaku UMKM } \\
\text { mencatat setiap transaksi keuangan usahanya }\end{array}$ & untuk & 52 tenant & $\begin{array}{c}\text { Penyusunan buku } \\
\text { kas }\end{array}$ \\
\hline 4 & $\begin{array}{l}\text { Meningkatkan partisipasi pelaku UMKM } \\
\text { membuat laporan keuangan sederhana }\end{array}$ & untuk & 52 tenant & $\begin{array}{c}\text { Penyusunan } \\
\text { laporan keuangan }\end{array}$ \\
\hline
\end{tabular}

Sumber: Data primer, 2020

\section{HASIL DAN PEMBAHASAN}

Program kegiatan pendampingan UMKM ini berlangsung selama 6 bulan. Pendampingan ini dimulai dengan memberikan sosialisasi kepada UMKM yang sudah ditunjuk dan bersedia diberikan pendampingan secara intensif. Kegiatan ini dilaksanakan bekerja sama dengan Kantor Pelayanan Pajak (KPP) Pratama Cirebon 1. Kegiatan ini dimulai pada bulan Oktober sampai dengan Februari 2020. Kegiatan dilaksanakan secara langsung dan berkala. Metode yang digunakan cukup efektif dilakukan karena penyampaian materi dilakukan hanya satu hari sisanya adalah pendampingan langsung ke pelaku UMKM yang berada di dalam binaan KPP Pratama Cirebon 1. Kegiatan pendampingan dilakukan selama 2 bulan yaitu bulan Januari sampai dengan Februari 2020. Secara umum kegiatan pendampingan yang dilakukan sebagai berikut: 
Tabel 2. Rangkuman Pelaksanaan Kegiatan Pendampingan

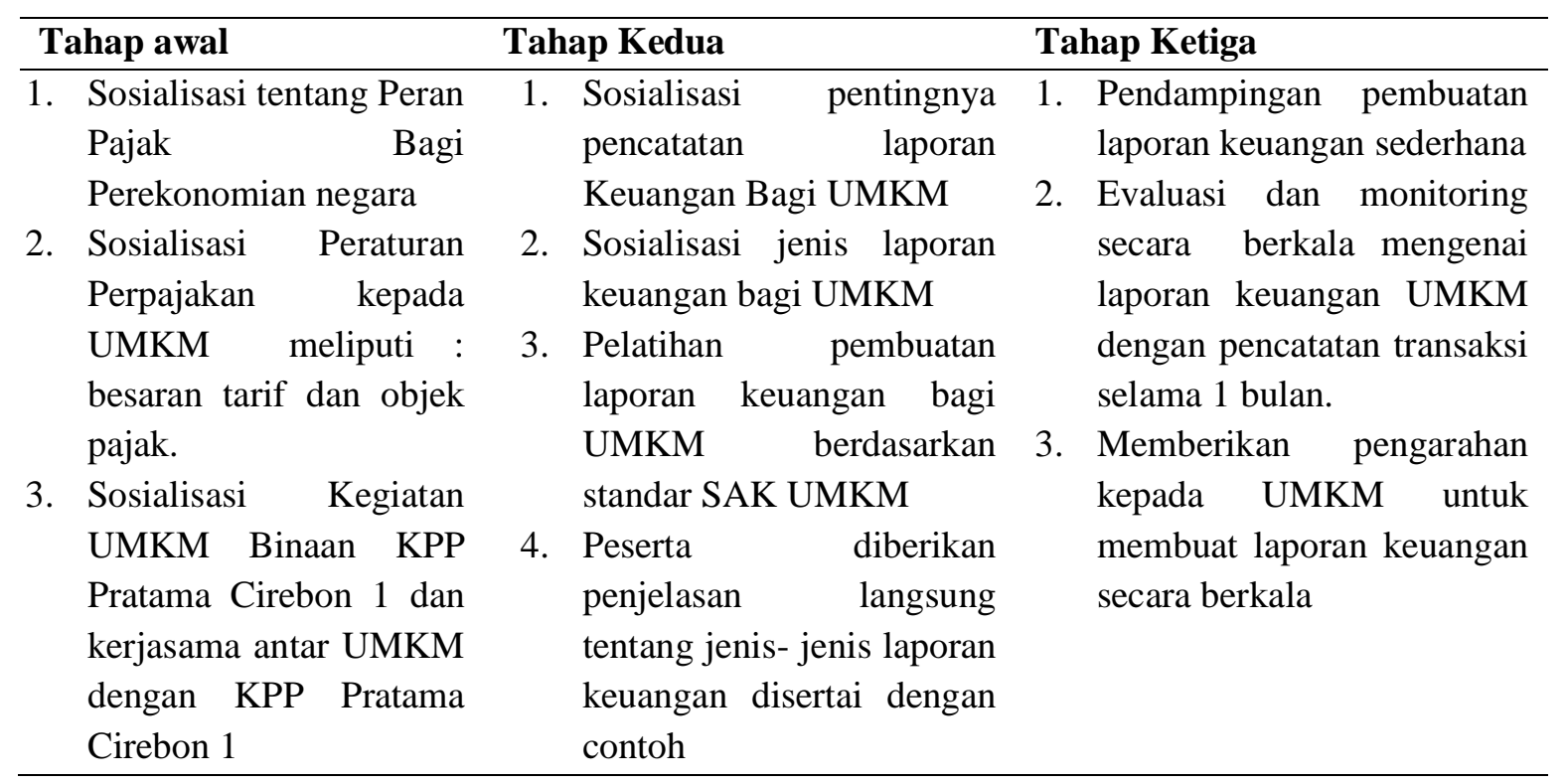

Sumber: Data primer, 2020

Keberhasilan program pendampingan dapat dilihat pada setiap pemberian materi dilakukan evaluasi dan monitoring. Hal ini bertujuan untuk melihat perubahan perilaku para peserta UMKM terhadap materi yang diberikan. Proses evaluasi dengan melihat kondisi awal, saat pendampingan, dan setelah pendampingan. Adapun Matrik Evaluasi Kegiatan Program Pendampingan Pengembangan UMKM dapat dilihat pada tabel berikut:

Tabel 3. Matrik Pendampingan UMKM Kota Cirebon

\begin{tabular}{|c|c|c|c|c|}
\hline No. & Materi & Kondisi Awal & Pada Saat Pendampingan & $\begin{array}{l}\text { Setelah } \\
\text { Pendampingan }\end{array}$ \\
\hline 1 & $\begin{array}{l}\text { Sosialisasi } \\
\text { Peraturan } \\
\text { Pajak } \\
\text { UMKM }\end{array}$ & $\begin{array}{l}\text { Peserta tidak } \\
\text { memiliki } \\
\text { pengentahuan terkait } \\
\text { perpajakaan } \\
>\text { Peserta tidak } \\
\text { mengetahui peraturan } \\
\text { mengenai pajak } \\
\text { UMKM yang berlaku } \\
\text { di Indonesia }\end{array}$ & $\begin{array}{l}\text { Peserta sedikit paham } \\
\text { tentang peraturan pajak } \\
\text { yang berlaku bagi } \\
\text { UMKM } \\
>\text { Peserta banyak } \\
\text { memberikan pertanyaan } \\
\text { terkait perpajakan di } \\
\text { Indonesia } \\
>\text { Peserta memberikan } \\
\text { contoh kasus pengenaan } \\
\text { tarif pajak untuk } \\
\text { UMKM }\end{array}$ & $\begin{array}{l}\text { Peningkatan } \\
\text { kepatuhan } \\
\text { perpajakan } \\
\text { dikalangan peserta } \\
\text { UMKM } \\
>\text { Peserta dapat } \\
\text { menghitung dasar } \\
\text { pengenaan pajak } \\
\text { bagi UMKM }\end{array}$ \\
\hline 2 & $\begin{array}{l}\text { Sosialisasi } \\
\text { pentingnya } \\
\text { laporan }\end{array}$ & $\begin{array}{l}\text { Peserta belum dapat } \\
\text { memilih transaksi } \\
\text { yang seusai dengan }\end{array}$ & $\begin{array}{l}\text { Peserta antusisas } \\
\text { mendengarkan } \\
\text { penyampaian materi }\end{array}$ & $\begin{array}{l}\text { Peserta menyadari } \\
\text { pentingnya } \\
\text { memishkan } \\
\text { keungan usaha }\end{array}$ \\
\hline
\end{tabular}




\begin{tabular}{|c|c|c|c|c|}
\hline No. & $\begin{array}{l}\text { keuangan } \\
\text { bagi UMKM }\end{array}$ & $\begin{array}{l}\text { bidang usaha yang } \\
\text { dijalankan } \\
\text { Modal yang kecil } \\
\text { menyebabkan peserta } \\
\text { masih meyatukan } \\
\text { pengeluaran untuk } \\
\text { pribadi dengan } \\
\text { pengeluaran usaha } \\
>\text { Peserta belum dapat } \\
\text { memahami sistem } \\
\text { transaski keungan } \\
\text { usaha }\end{array}$ & $\begin{array}{l}\text { Peserta mulai terbuka } \\
\text { wawsanya mengenai } \\
\text { transaksi keuangan dalam } \\
\text { dunia usaha } \\
>\text { peserta memberikan } \\
\text { pertanyaan sesuai contoh } \\
\text { usaha yang dijalankan } \\
>\text { peserta mulai memahami } \\
\text { manfaat dari pembuatan } \\
\text { laporan keuangan } \\
\text { usahanya }\end{array}$ & $\begin{array}{l}\text { Setelah } \\
\text { Pendampingan } \\
\text { dengan keuangan } \\
\text { pribadi } \\
>\quad \text { Peserta sudah } \\
\text { dapat memahami } \\
\text { tujuan pembuatan } \\
\text { laporan keuangan } \\
>\text { Peserta sudah } \\
\text { dapat memahami } \\
\text { pentingnya } \\
\text { membuat laporan } \\
\text { keuangn bagi } \\
\text { usahanya }\end{array}$ \\
\hline 3 & $\begin{array}{l}\text { Praktikum } \\
\text { Pencatatan } \\
\text { Transaksi } \\
\text { Keuangan } \\
\text { Bagi UMKM }\end{array}$ & $\begin{array}{l}\text { - Peserta belum } \\
\text { mencatat seluruh } \\
\text { transaksi keungan } \\
\text { yang dilakukan setiap } \\
\text { harinya } \\
\text { - Peserta belum } \\
\text { menyadari pentingnya } \\
\text { pengumpulan bukti } \\
\text { transaksi keuangan } \\
\text { untuk kegiatan } \\
\text { usahanya } \\
\text { - Peserta belum dapat } \\
\text { mengidentifikasi } \\
\text { setiap transaksi yang } \\
\text { terjadi dari aktivitas } \\
\text { usahanya } \\
\text { - Peserta belum bisa } \\
\text { menganalisis jenis } \\
\text { transaksi berdasarkan } \\
\text { sistem pembukuan } \\
\text { akuntansi dan } \\
\text { persamaan dasr } \\
\text { akuntansi. }\end{array}$ & 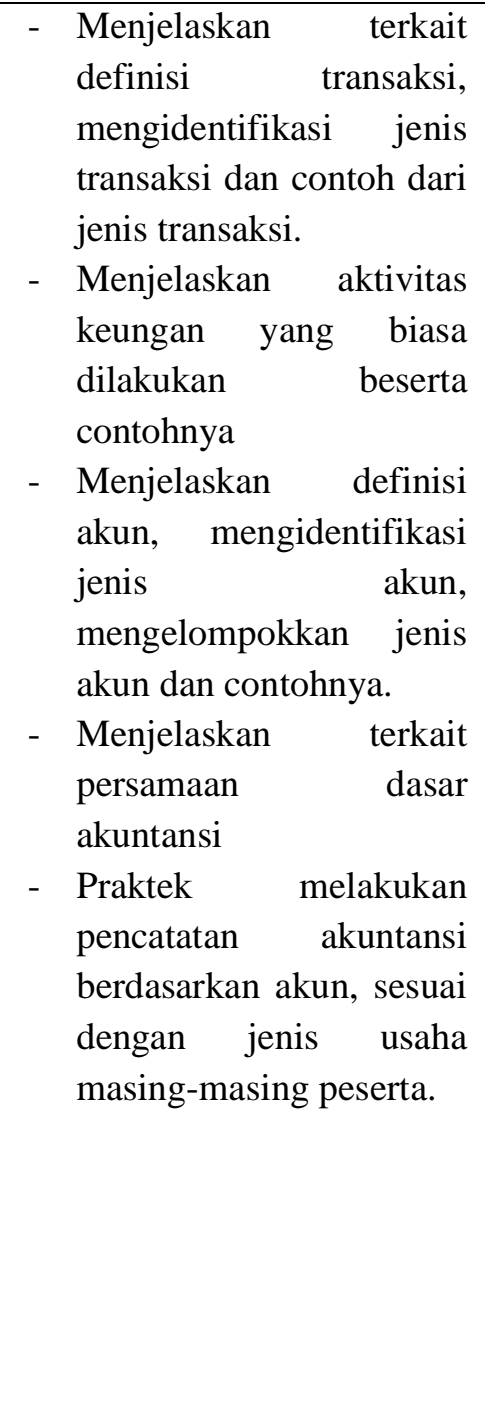 & 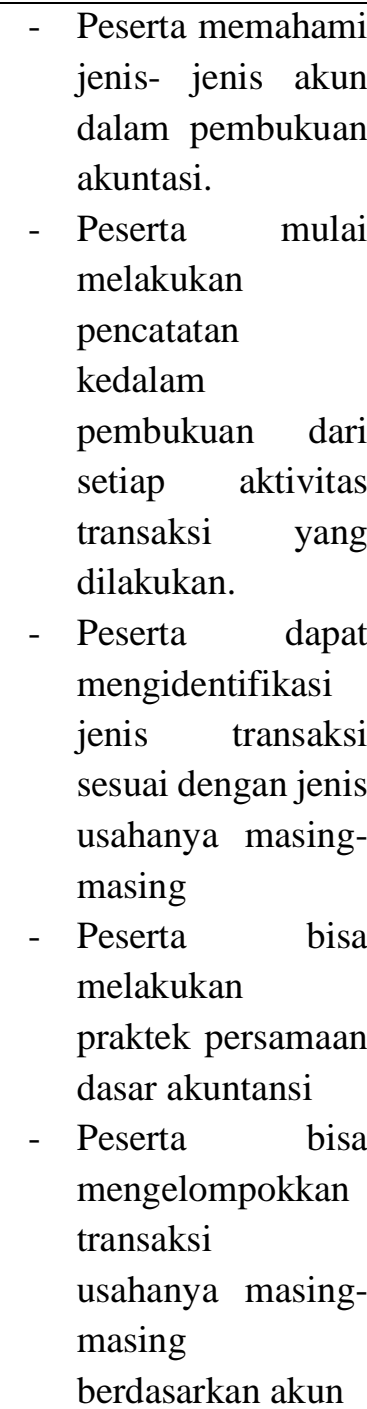 \\
\hline
\end{tabular}

Sumber: Data primer, 2020

Tabel diatas menunjukkan bahwa seluruh peserta dalam program pendampingan ini telah berhasil mengikuti rangkaian kegiatan dengan baik. Antusiasme yang begitu besar tercermin dari banyaknya mitra UMKM yang berhasil menyelesaikan pelaporan keuangan dari kegiatan usaha 
yang dilakukannya. Beberapa peserta awalnya mengalami kesulitan, namun selama proses pendampingan akhirnya peserta dapat menyelesaikan laporan keuangan usahnya dengan baik. Selain itu sebagian besar peserta juga telah melaporkan pajak tahunannya melalui system SPT Tahunan yang dijelaskan pada table berikut:

Tabel 4. Jumlah UMKM yang Lapor SPT Sebelum dan Sesudah Pelatihan

\begin{tabular}{lll}
\hline Keterangan & Sebelum & Sesudah \\
\hline Jumlah UMKM yang mengikuti pendampingan & 52 Tenant & 52 tenant \\
\hline Jumlah UMKM yang sudah lapor SPT & 5 Tenant & 48 Tenant \\
\hline Jumlah UMKM yang sudah bayar Pajak & 1 Tenant & 50 tenant \\
\hline
\end{tabular}

Sumber: Data primer, 2020

Program Pemberdayaan ini berjalan dengan baik dengan mendapat antusiasme yang cukup baik dari peserta. Hal ini terlihat dari banyaknya peserta yang sudah melaporkan pajak tahunan dan membayar pajak sesuai dengan ketentuan. Hampir seluruh peserta yang belum melakukan kewajiban perpajakannya melakukan kewajibannya setelah mengikuti program ini. Hal ini mengindikasikan bahwa program pemberdayaan ini berhasil dilaksanakan sehingga secara tidak langsung menambah pendapatan negara melalui perpajakan. Keberhasilan program ini memberikan apresiasi yang cukup tinggi dari masyarakat untuk pembangunan Negara melalui sektor pajak.

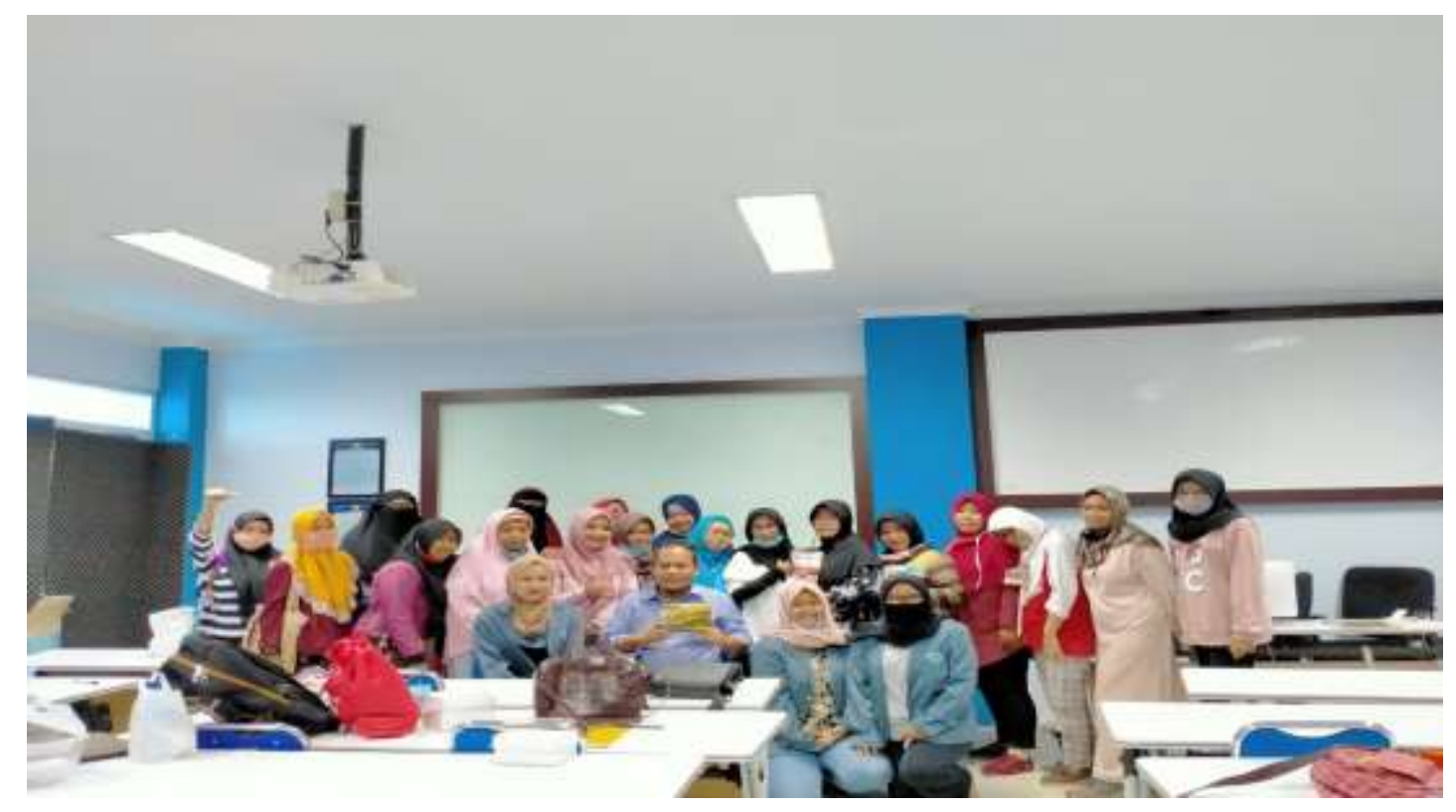

Gambar 1. Kegiatan Sosialisasi Pentingnya Laporan Keuangan dan pajak 


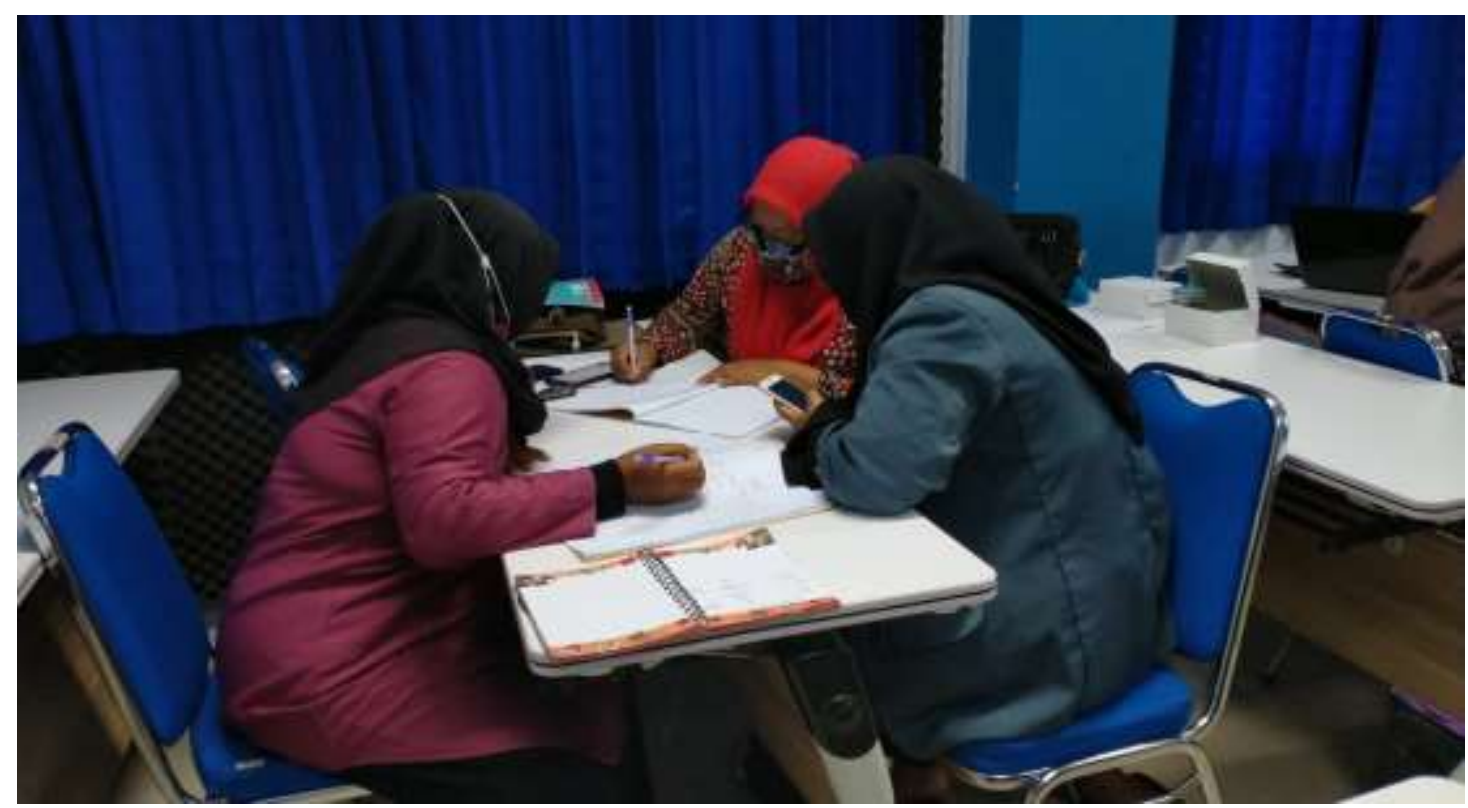

Gambar 2. Pendampingan Pembuatan Laporan Keuangan dan Perpajakan

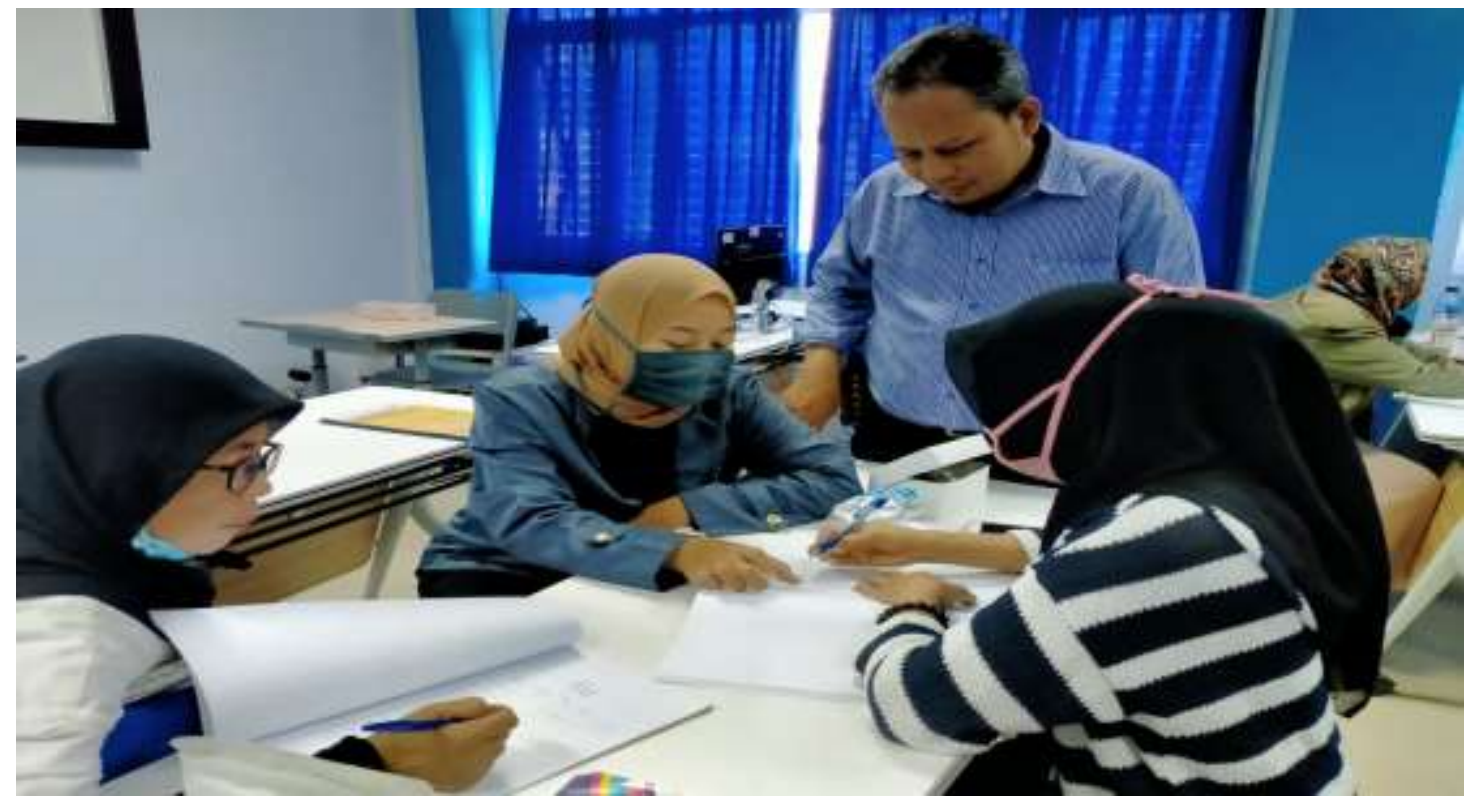

Gambar 3. Monitoring Pembuatan Laporan Keuangan dan Perpajakan

\section{KESIMPULAN DAN SARAN}

Pelaksanaan kegiatan Pendampingan Pengembangan laporan Keuangan dan Pelaporan Pajak bagi UMKM di Kota Cirebon memberikan banyak manfaat untuk pelaku UMKM diantaranya Pelaku UMKM berhasil meningkat kesadarannya akan pelaporan pajak bagi UMKM dan pentingnya Pajak bagi pembangunan negara. Kepatuhan pelaporan pajak meningkat setelah mengikuti sosialisasi dan pelatihan ini. 
Selain itu Pelaku UMKM dapat meningkatkan potensi usahanya melalui perencanaan keuangan yang baik serta pelaporan keuangan yang tertib dan terstruktur. Sehingga mudah dibaca oleh investor dan kreditor pada saat pelaku UMKM membutuhkan tambahan modal. Dengan adanya kegiatan ini pelaku UMKM sudah dapat memisahkan kegiatan usahanya dengan pengeluaran pribadinya. Sehingga peningkatan kapasitas produksi dapat meningkat. Tujuan utamanya adalah peningkatan omzet penjualan produk mereka. Sehingga akan berdampak pada peningkatan pemasukan pajak bagi negara.

Adapun saran kegiatan Pendampingan Pengembangan laporan Keuangan dan Pelaporan Pajak bagi UMKM di Kota Cirebon yaitu diperlukan dukungan dari semua stakeholder (KPP Pratam Cirebon, pemerintah daerah dan akademisi) untuk mensosialisasikan stiap peraturan perpajakan yang berlaku sehingga masyarakat dapat mengetahuinya. Sehingga kesadaran masyarakat akan pentingnya perpajakan dapat meningkat.

Tercapainya keberhasilan program ini dapat dilanjutkan dengan program lainya yang mengarah pada peningkatan kapasitas UMKM Tenant baik dalam bentuk produk maupun kemasan, serta fasilitasi promosi melalui pameran tingkat Kabupaten, Provinsi, maupun nasional yang dapat meningkatkan omzet dari pelaku UMKM. Sehingga Perlu dihasilkan program pengembangan UMKM Tenant melalui teknologi informasi dengan didukung oleh pelaporan keuangan scara elektrik by sistem sesuai dengan perkembangan jaman.

\section{UCAPAN TERIMA KASIH}

Terima kasih kami sampaikan kepada Lembaga Pengabdian Masyarakat (LPM) Universitas Swadaya Gunung Jati Cirebon yang telah memberikan bantuan baik moril maupun materil atas terselenggaranya kegiatan Pengabdian kepada masyarakat. Terima kasih kami ucapkan kepada Dekan Fakultas Ekonomi yang telah memberikan banyak motivasi dan dorongan kepada kami untuk terus memberikan pengabdian kepada masyarakat. Ucapan terima kasih kami sampaikan kepada kepada Kepala Kantor Pelayanan Pajak (KPP) Pratama Cirebon 1 beserta jajarannya yang telah memberikan bantuan untuk suksesnya kegiatan pengabdian ini. Tak lupa kami sampaikan banyak terima kasih kepada mitra UMKM yang tergabung dalam kelompok binaan KPP Pratama Cirebon 1 yang telah bersedia menjadi peserta dalam kegiatan pengabdian kali ini. Semoga program pengabdian ini dapat memberikan manfaat dan keberkahan bagi semua pihak. 


\section{DAFTAR PUSTAKA}

Astuti, Ramlah Puji, Kartono Kartono, \& Rahmadi Rahmadi. 2020. "Pengembangan UMKM Melalui Digitalisasi Tekonolgi Dan Integrasi Akses Permodalan.” ETHOS: Jurnal Penelitian dan Pengabdian kepada Masyarakat 8(2): 248-56.

BPS. 2019. "Statistik Daerah Kota Cirebon 2019."

Dinas Perdagangan, Koperasi, Usaha Kecil dan Menengah. 2019. "Cirebon Satu Data." : 1-2. https://satin.cirebonkota.go.id.

Fauziah, Ulfah, \& Bernard E Tidajoh. 2018. 2 Perencanaan Pajak Untuk Usaha Mikro, Kecil, Dan Menengah.

Hardiningsih, Pancawati, \& Rachmawati Oktaviani. 2013. "Implementasi Pajak Penghasilan Usaha Mikro Kecil Dan Menengah (Studi Kasus UMKM Semarang).” : 1-11.

Ibrahim, Syarif. 2014. “Kajian Pph Final Umkm_pkpn.” Pengenaan PPH Final Untuk Wajib Pajak Dengan Peredaran Bruto Tertentu, Sebuah Konsep Kesederhanaan Pengenaan PPH Untuk Meningkatkan Voluntary Tax Compliance.

Inasius, Fany. 2015. "Pajak Penghasilan Orang Pribadi Usaha Mikro Dan Kecil Di Indonesia: Kebijakan Dan Implikasi.” Binus Bussiness Review.

Muizu, Wa Ode Zusnita. 2017. "Pendampingan Pengelolaan Umkm Di Kecamatan Talun Kabupaten Cirebon-Jawa Barat." Prosiding Seminar Hasil Pengabdian Kepada Masyarakat (SNP2M) 2017 (pp.100-103) 2017: 100-103.

PP. 2013. "Peraturan Pemerintah Republik Indonesia Nomor 46 Tahun 2013 Tentang Pajak Penghasilan Atas Penghasilan Dari Usaha Yang Diterima Oleh Wajib Pajak." Lembar Negara 66(1997): 37-39.

Prabantari, F., \& M. Ardiyanto. 2017. “Implementasi Pajak Penghasilan Berdasarkan Peraturan Pemerintah Nomor 46 Tahun 2013 (Studi Pada UMKM Di Jawa Tengah Dan Daerah Istimewa Yogyakarta).” 6(4): 399-410. 